\title{
MARGALEF INDEX, SIMPSON INDEX AND SHANNON-WEAIVER INDEX CALCULATION FOR DIVERSITY AND ABUDANCE OF BEETLE IN TROPICAL FOREST
}

\author{
Ibnu Sina and Iskandar Zulkarnaen \\ University of Pamulang \\ J1. Surya Kencana No. 1, South Tangerang, Indonesia
}

\begin{abstract}
Field sampling was conducted from July to August 2019 to determine the diversity and abundance of beetle fauna at Gayo Lues Forest, Takengon, Central Aceh. The study was conducted at two sites namely trail I and trail II. The beetles were sampled using 2 light traps, 2 malaise traps and 20 pitfall traps. Total of 219 beetle specimens comprising of 67 species from 24 families were collected. Light trap collected the most number of beetles $(\mathrm{N}=117)$ and Margalef index showed that the most abundant beetle was collected by light trap (Margalef index, 27.551). Shannon-Weiner index shows that the most specious beetle was caught by light traps (4.399). The results showed that the most efficient trap was light trapping. Trail I has the most abundance (Margalef Index: 18.572) but trail II was the most specious (Shannon Weiner Index: 4.176) beetle fauna, whereas trail II has the least abundance (Margalef Index: 17.295) and Campsite has least diverse (Shannon Weiner Index: 3.769). The most abundant family caught was Staphylinidae (Margalef index : 2.667) and specious beetle family caught was the Chrysomelida (Shannon Weiner : 1.846) followed by the ground beetle family Scarabaeidae (Shannon Weiver:1.828). Result of this findings showed that Gayo Lues Forest is an undisturbed forests and has been preserved well.
\end{abstract}

Keywords : Beetle, Diversity, Abundance, Takengon, Gayo

\section{INTRODUCTION}

Tropical forest ecosystems are under enormous pressure all over the world (Sundufu and Rashida, 2008). Many forest areas in the tropics may only persist as production areas (Brown, 1997; Hunter, 1999), and pressure on unprotected forests is very likely to escalate (Terborg, 1999; Lewis, 2000). Forest management in temperate and boreal regions is often based on a strong foundation of applied ecological research. Increasingly, this has allowed the needs of dead wood associated insects to be addressed. However, there has been very little equivalent research in tropical forests, where insect faunas are likely to be much richer and where forestry is usually subject to weaker environmental controls. As in temperate regions, tropical beetles are likely to be highly specious, and to exhibit a wide range of lifehistories. Coupled with their relative ease of capture, storage and identification (compared to many other invertebrates), these attributes make beetles potentially valuable in detecting 
impacts of tropical rainforest management that should equally be felt by many other groups of more cryptic forest-dwelling organisms sharing an association with the mature timber habitat (Simon Grove, 2001).

Insect plays significant role in ecosystem dynamics such as at forest, freshwater lakes, ponds, rivers, mountain and agricultural and also in our life. Tropical forest insect dominate the number of described and estimated species on earth. Understanding the degree of insect specialization to vertical zones, host plants and other resources within tropical forests is of central importance to global species richness estimates (Erwin, 1982; Stork, 1988; Hammond, 1995; Odegaard, 2000; Novotny et al., 2002). Tropical beetles are likely to be highly specious, and to exhibit a wide range of life-histories. Coupled with their relative ease of capture, storage and identification (compared to many other invertebrates), these attributes make beetles potentially valuable in detecting impacts of tropical rainforest management that should equally be felt by many other groups of more cryptic forest-dwelling organisms sharing an association with the mature timber habitat.(Grove, 2001). Beetles are well represented in all terrestrial habitats by many species, genera, and families, which are often used as indicators of environmental change because of their great habitat specificity (Forsythe, 1987; Lovei and Sunderland, 1996). Due to their small length, diversity and sensitivity to environmental stress have been considered as good indicators of habitat heterogeneity.

The tropical forest is one of the richest habitats for plant and animal diversity (Prance, 1982) and some simple but informative work can be undertaken comparing animal or plants diversity across different habitats especially for habitat was disturbance cause of deforestation, agriculture, plantation or climate change. A study on abundance and diversity of beetles Gayo Lues forest was conducted to determine that the beetles have not been affected by disturbed environment.

\section{MATERIAL AND METHODS}

\subsection{Study area and sampling duration}

A study on beetle fauna was conducted from July to August 2019 at Gayo Lues forest area, Central Aceh. Samplings were made at two sites namely trail I and trail II area. 


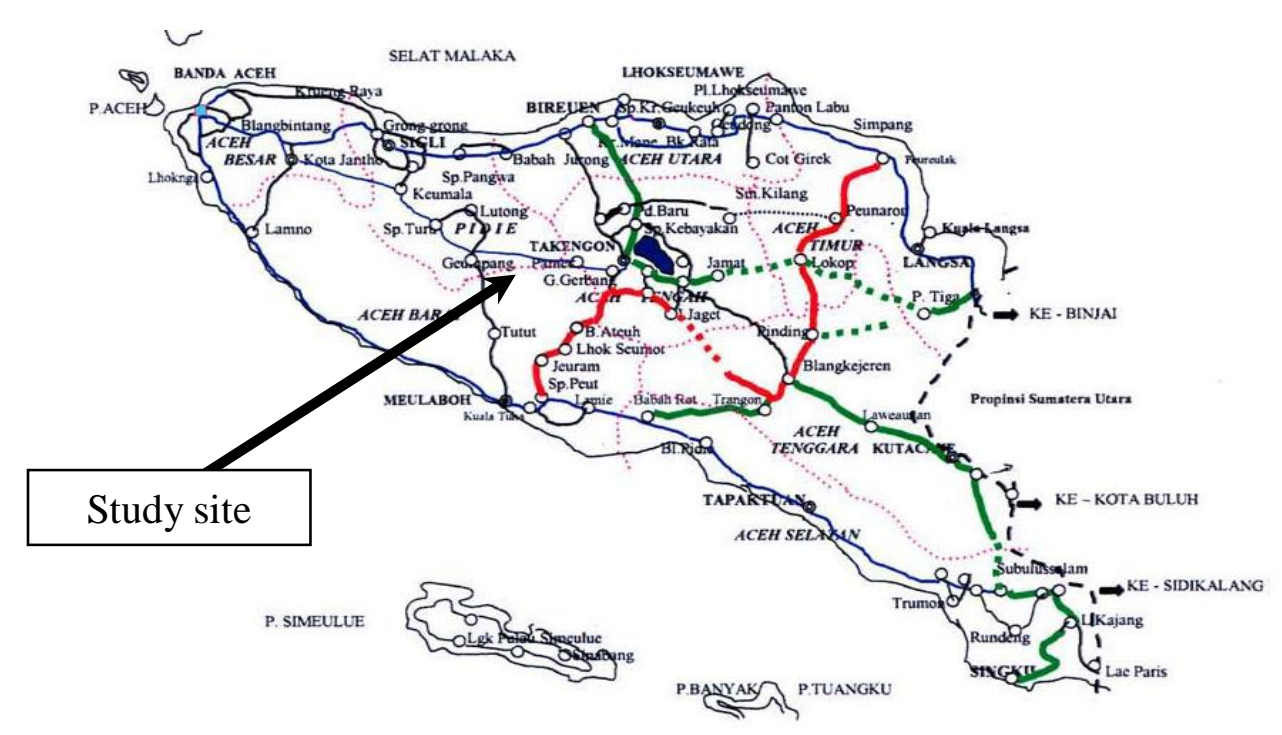

\subsection{Sampling methods}

To ensure maximum assemblage, several methods of collection were employed following Fauziah and Ibnu Sina (2009). Throughout the expedition, a total of four malaise traps and seventh five pitfall traps were set up in the morning at $0800 \mathrm{~h}$ for 24 hours at each sampling site in total of 3 days sampling. Six light traps were set up before nightfall and generator was switched on to collect beetles attracted to light.

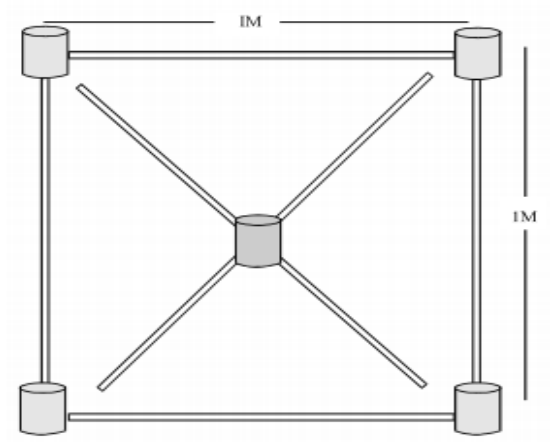

Figure 2. Set up pit fall for each trail (Fauziah et al., 2008) 


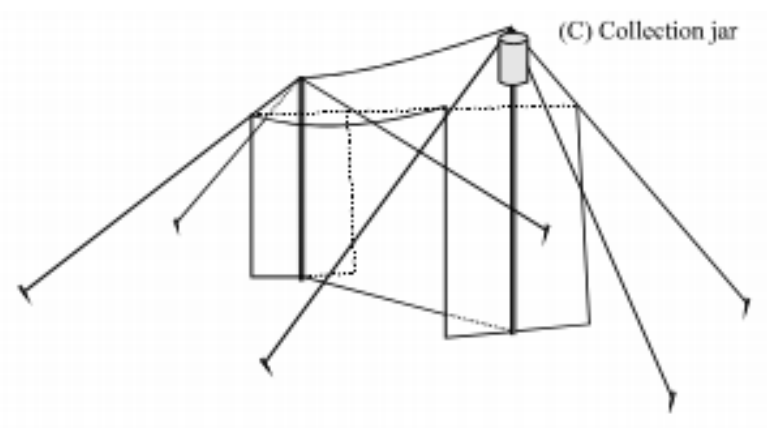

Figure 3. A malaise trap set up one meter froum ground (Fauziah et al., 2008)

\subsection{Sorting, preservation and identification}

Specimens were sorted to family level according to Borror and Delong (1974) and Triplehorn and Johnson (2004) and the specimens were preserved in $70 \%$ alcohol in scintillation vials. The specimens were brought back to Jakarta, pinning and drying in oven. The beetle species were identified using key identification (Borror and Delong, 1974)

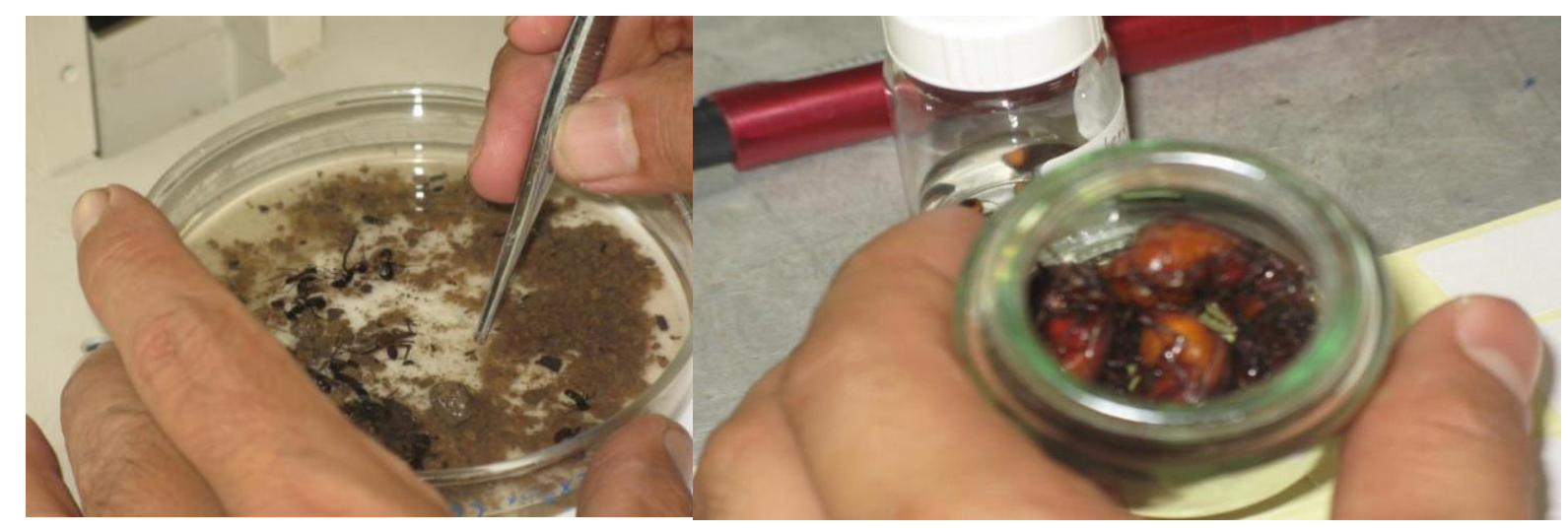

Figure 4. Sorting beetle into families, genus and species level

\subsection{Ecological indices calculation.}

Species richness and abundance of beetle fauna were determined using Margalef index and the diversity was calculated using Simpson index and Shannon-Weaver index.

$$
R=\frac{S-1}{\ln N}
$$


S: the number of species recorded in a sample; with that of sample size N (Waite, 2000). Abundance increased proportionately with the value of Margalef index.

The diversity of each different family of beetle and the overall for Coleoptera was determined using Shannon-Weaver Index,

$$
D=1-\sum_{i=1}^{N}\left(p_{i}\right)^{2}
$$

This index assumes that each species was represented in each sample and that there was random sampling of individuals from an infinitely large population. Diversity increases with the increase in the value of the index. Shannon-weaver index has a maximum value of 5 .

Based on the probability that two unrelated strains sampled from the test population will be placed into different typing groups. This probability can be calculated by Simpson's index of diversity, which was developed for the description ofs pecies diversity within an ecological habitat. This index can be derived from elementary probability theory and is given by the following equation:

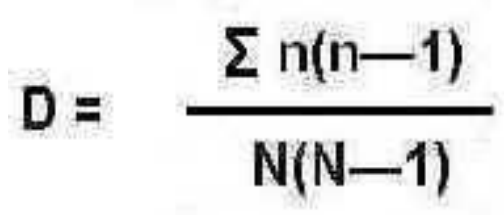

\section{RESULTS}

A summary of beetles sampled at Gayo Lues forest is given in Table 1. Total of 219 beetle specimens comprising of 67 species from 24 families were collected. The checklist of the beetles collected at Chamah Highland shown in Table 2. The beetles were abundant at all trails locations as shown by the values of Margalef index (Table 3). Light trap collected the most number of beetles $(\mathrm{N}=117)$ and Margalef index showed that the most abundant beetle was collected by light trap (Margalef index, 27.551). Shannon-Weiner index shows that the most specious beetle was caught by light traps (4.399). The results showed that the most efficient trap was light trapping. Trail I has the most abundance (Margalef Index: 18.572) but trail II was the most specious (Shannon Weiner Index: 4.176) beetle fauna, whereas trail II has the least abundance (Margalef Index: 17.295) and Campsite has least diverse (Shannon Weiner Index: 3.769).The most abundant family caught was Staphylinidae (Margalef index : 2.667) and specious beetle family caught was the Chrysomelida (Shannon Weiner : 1.846) followed by the ground beetle family Scarabaeidae (Shannon Weiver:1.828). 
Table 1. A summary of beetles collected from three study sites in Gayo Lues Forest

\begin{tabular}{lccccc}
\hline Sites & Individual & Family & Species & Margalef index & Shannon Weiner index \\
\hline Trail I & 102 & 11 & 28 & 15.145 & 0.938 \\
Trail II & 117 & 13 & 39 & 16.573 & 0.954 \\
\hline Total & 219 & 24 & 67 & 31.718 & 0.958 \\
\hline
\end{tabular}

Table 2. Checklist of beetles at Gayo Lues forest and value of ecological indexes according to family.

\begin{tabular}{|c|c|c|c|c|c|}
\hline Family & Morpho-sp & Ind & Margalef Index & Simpson Index & Shannon-Weaver Index \\
\hline Anobiidae & Ano B & 1 & & & \\
\hline \multirow[t]{2}{*}{ Anthribidae } & Litocerus deyrol & 1 & 1,442695041 & & 0,69315 \\
\hline & Litocerus payiei & 1 & & & \\
\hline \multirow[t]{2}{*}{ Bostrichidae } & Xyleborus celsus & 1 & 1,442695041 & & 0,69315 \\
\hline & Bost B & 1 & & & \\
\hline \multirow[t]{2}{*}{ Byrrhidae } & Amphicyrta sp & 1 & 1,442695041 & & 0,69315 \\
\hline & Byrr B & 1 & & & \\
\hline \multirow[t]{4}{*}{ Carabidae } & Agonum sp & 7 & & & \\
\hline & Calleida punctata & 15 & 0,943973941 & 0,456521739 & 0,91797 \\
\hline & Cara B & 1 & & & \\
\hline & Cara C & 1 & & & \\
\hline Cerambycidae & Haplidus sp & 1 & & & \\
\hline \multirow[t]{7}{*}{ Chrysomelidae } & Phydanis sp & 3 & & & \\
\hline & Lilioceris sp & 2 & & & \\
\hline & Monoleptites sp & 1 & 2,502194349 & 0,090909091 & 1,84622 \\
\hline & Diabrotica $\mathrm{sp}$ & 2 & & & \\
\hline & Chry D & 1 & & & \\
\hline & Chry E & 1 & & & \\
\hline & Chry F & 1 & & & \\
\hline Cicindelidae & Cicindela versicolor & 1 & & & \\
\hline \multirow[t]{2}{*}{ Cleridae } & Monophylla sp & 1 & 0,910239227 & 0,333333333 & 0,63651 \\
\hline & Trichodes sp & 2 & & & \\
\hline Coccinelidae & Cocinella $\mathrm{sp}$ & 2 & & 1 & \\
\hline \multirow[t]{5}{*}{ Curculionidae } & Lignyodes $\mathrm{sp}$ & 1 & & & \\
\hline & Rhyncophoruss sp & 2 & & & \\
\hline & Odontochorinus sp & 2 & 2,055593369 & 0,095238095 & 1,54983 \\
\hline & Curcu D & 1 & & & \\
\hline & Curcu E & 1 & & & \\
\hline Dystiscidae & Dys E & 1 & & & \\
\hline \multirow[t]{2}{*}{ Elateridae } & $\begin{array}{l}\text { Alaus nubilus } \\
\text { Monocrepidus }\end{array}$ & 1 & & & \\
\hline & paradigophorus & 1 & & & \\
\hline
\end{tabular}




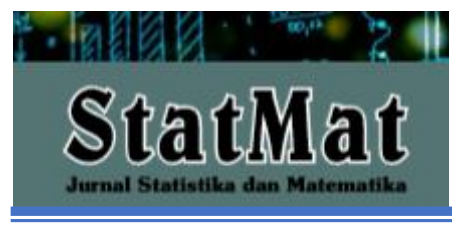

P-ISSN: 2655-3724

STATMAT (Jurnal Statistik dan Matematika), Vol. 1, No. 2, Juli 2019

Halaman: 83-93

@Prodi S-1 Matematika FMIPA Unpam

\begin{tabular}{|c|c|c|c|c|c|}
\hline Family & Morpho-sp & Ind & Margalef Index & Simpson Index & Shannon-Weaver Index \\
\hline & Ela C & 1 & 2,164042561 & & 1,38629 \\
\hline & Ela D & 1 & & & \\
\hline Erotylidae & $\begin{array}{c}\text { Glischrochilus } \\
\text { fasciatus } \\
\end{array}$ & 1 & & & \\
\hline Hydrophilidae & Merosternum $s p$ & 1 & & & \\
\hline Lampyridae & Photinus sp & 1 & & & \\
\hline Lucanidae & Dorcus sp & 1 & & & \\
\hline Lycidae & Leptoceletes $\mathrm{sp}$ & 1 & & & \\
\hline Nitidulidae & $\begin{array}{c}\text { Brachypeplus } \\
\text { orientalls } \\
\text { Niti B } \\
\end{array}$ & $\begin{array}{l}1 \\
1 \\
\end{array}$ & 1,442695041 & & 0,69315 \\
\hline Platypodidae & Platypus linearis & 15 & & 1 & \\
\hline Scarabaeidae & $\begin{array}{c}\text { Anomala cusripes } \\
\text { Anomala cusripes } \\
\text { Anomala sp } 2 . \\
\text { Scara D } \\
\text { Scara E } \\
\text { Scara F } \\
\text { Scara G } \\
\text { Scara H } \\
\end{array}$ & $\begin{array}{l}1 \\
1 \\
1 \\
1 \\
3 \\
1 \\
5 \\
1\end{array}$ & 2,652462272 & 0,142857143 & 1,82884 \\
\hline Scolytidae & $\begin{array}{c}\text { Poecilips varabilis } \\
\text { Scoly B } \\
\end{array}$ & $\begin{array}{l}11 \\
15 \\
\end{array}$ & 0,306927676 & 0,492307692 & 0,68127 \\
\hline Staphylinidae & $\begin{array}{c}\text { Paederus sp } \\
\text { Orphnebius } \mathrm{sp} \\
\text { Staphy C } \\
\text { Belonuchus } \mathrm{sp} \\
\text { Staphy E } \\
\text { Staphy F } \\
\text { Eleusis kratz } \\
\text { Staphy H } \\
\text { Staphy I } \\
\text { Staphy J } \\
\text { Staphy K } \\
\text { Hesperus sp } \\
\text { Staphy M } \\
\end{array}$ & $\begin{array}{c}66 \\
5 \\
2 \\
7 \\
1 \\
1 \\
3 \\
1 \\
1 \\
1 \\
1 \\
1 \\
1 \\
\end{array}$ & 2,660246896 & 0,532356532 & 1,18264 \\
\hline Tenebrionidae & $\begin{array}{c}\text { Eucyrtus pretiosus } \\
\text { Helops } \mathrm{sp} \\
\text { Tene C }\end{array}$ & $\begin{array}{l}2 \\
1 \\
2\end{array}$ & 1,242669869 & 0,2 & 1,05492 \\
\hline 24 & 67 & 219 & 12,24700715 & 0,108709313 & 3,14954 \\
\hline
\end{tabular}




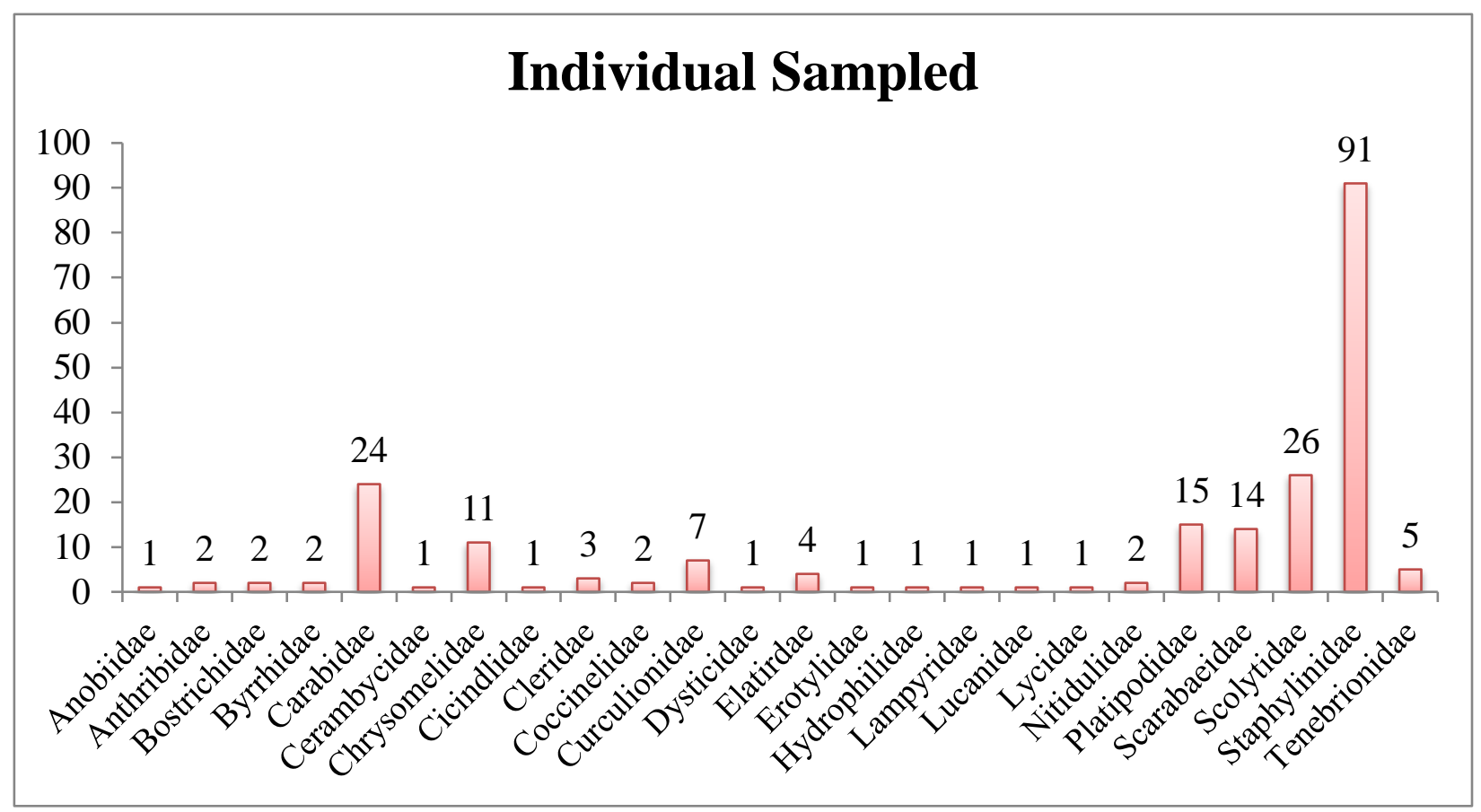

Fig 5. Number of individual of each family of beetle sampled at Gayo Lues Forest area

\section{Species Sampled}

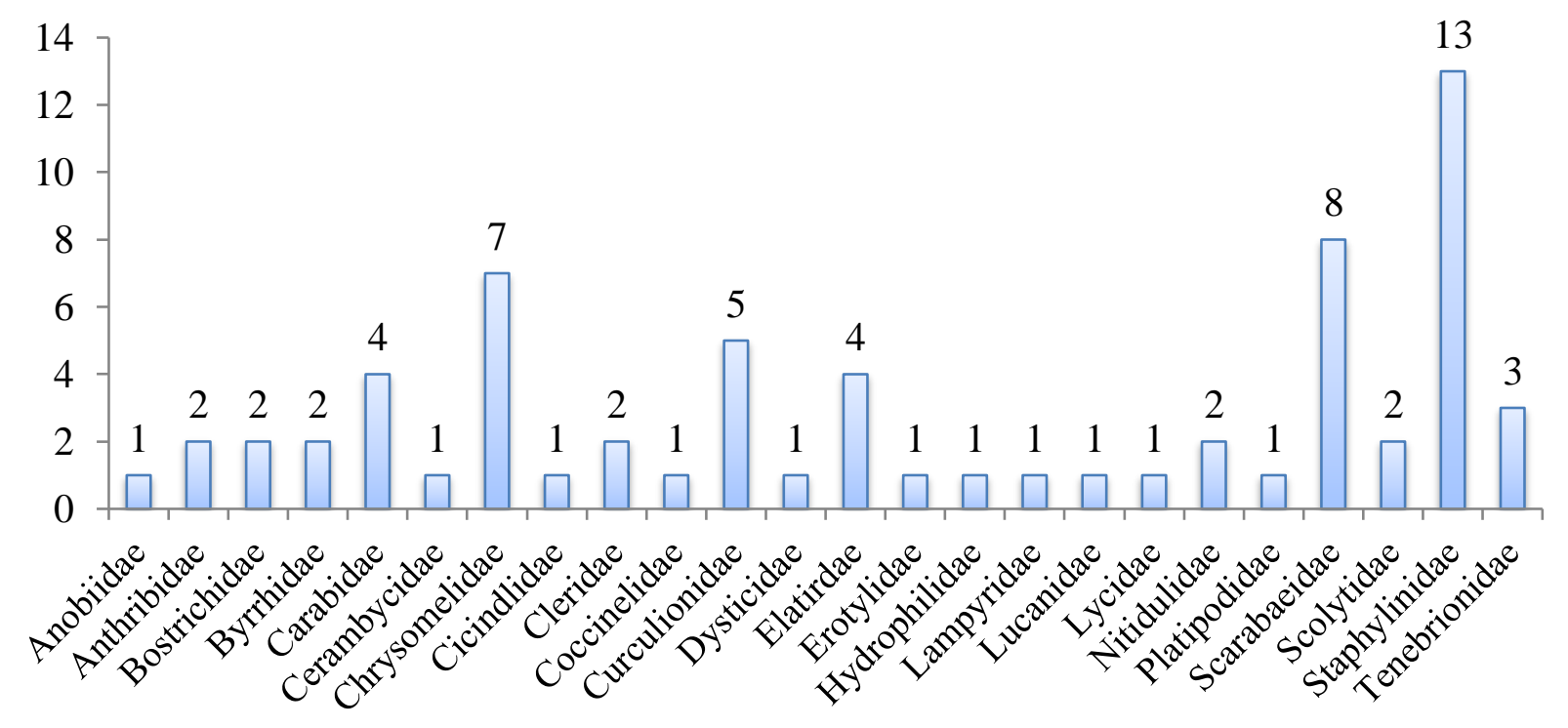

Fig 6. Number of species sampled from each family of Beetle at Gayo Lues forest area 
Figure 5 shows that most of the beetle specimens collected belongs to family Staphylinidae $(\mathrm{N}=91)$ followed by Scolytidae $(\mathrm{N}=26)$ and Carabidae $(\mathrm{N}=24)$. Figure 6 gives the number of species collected from each beetle family. The most number of species collected were from family Staphylinidae $(\mathrm{N}=13)$ followed by family Scarabaidae $(\mathrm{N}=8)$ and Chrysomelidae $(\mathrm{N}=7)$

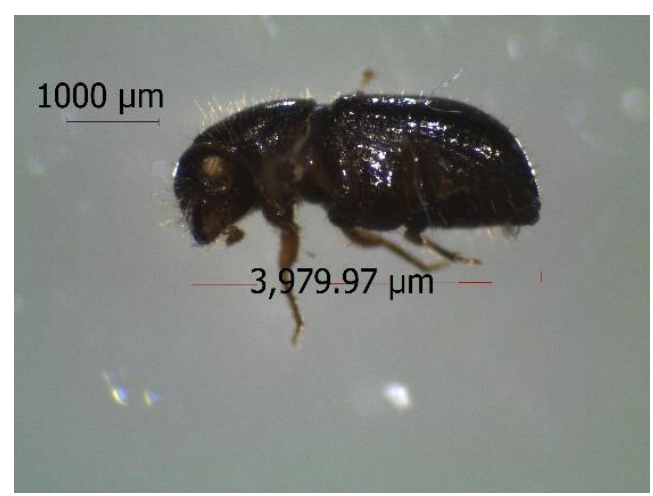

Fig 7. Poecilips varabilis

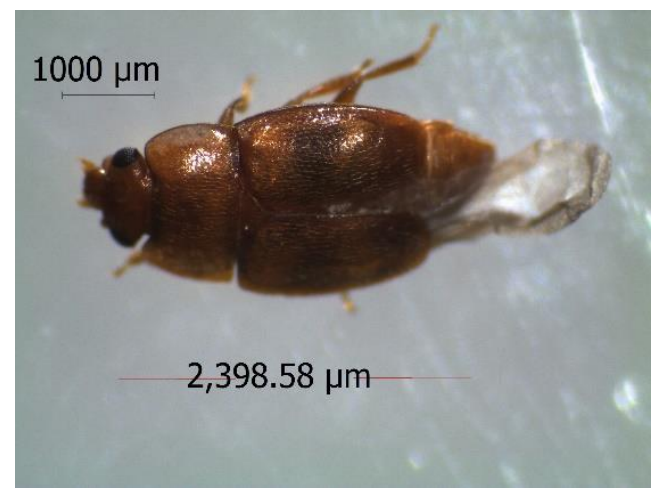

Fig 8. Unknown (Family: Rhipiphoridae)

\section{DISCUSSION}

Combining all study sites, there was a high abundance (Margelef index, 33.885) and high diversity (Simpson diversity index, 0.968: Shannon Weiner index, 4.534) of beetle fauna sampled at Gayo Lues forest, West Aceh. This is because the forests were still intact with no human activities for open site.

The findings of this study shown that, the most efficient trap was light trapping. Light trap method used light as an attraction to the insect approaching. According to Melbourne (1999), vegetation structure influences trap capacity to capture insects.

Result of this findings show that Gayo Lues forest is an undisturbed forests which have been preserved well. Tropical rainforest are home to a rich diversity of plants, birds, insects and other animals and they also play an important role in our global climate and provide aesthetic, recreational and medical benefits. For these reasons and others, it is critical that we understand how these forests generate and sustain their diversity and what we can do to help conserve them.

\section{ACKNOWLEDGEMENTS}

The authors would like to express appreciation to Head of District, Takengon, West Aceh for giving permission and guidence during the study. Thank you also goes to Dinas Kehutanan Kabupaten Aceh Tengah for assistance and helped for collecting sample in the field. This study is funded from Hibah Dikti 2018-2019 


\section{REFERENCES}

Borror, D.J. and D.M DeLong,. 1971. An Introduction to the Study of Insects. $3{ }^{\text {rd }}$ ed. Holt, Rinehart and Winston. New York. 1971.

Brown K. S. (1997). Diversity, distrurbance, and sustainable use of Neotropical forest: insect as indicators for conservation monitoring. Journal of Insect Conservation. Vol. 1: $25-42$.

Dagobert K. K., Mamadou D. and Jan K. (2010). Assessment of beetle abundance and diversity by four methods of capture in the west-central part of Oume, Ivory Coast. Journal of Animal and Plant Sciences. Vol. 6: 579-588.

Erwin, T. L. (1982). Tropical forests: their richness in Coleoptera and other arthropod species. Coleopt. Bull. Vol. 36: 74-82.

Fauziah A. (2005). The Beetle Assemblage of Langkawi Island. Malaysian Journal of Science, 24 (Langkawi Special Issue). pp. 185-198.

Fauziah Abdullah and Ibnu. Sina (2009) Rove Beetles (Coleoptera: Staphylinidae) of Lanjak Entimau, Sarawak, East Malaysia. International Journal of Zoological Research 5(3)126-135.

Fauziah Abdullah and Kamarulnizam Shamsulaman (2008) Beetle Fauna of Royal Belum In: Proceeding of "Seminar of Scientific Expedition on Biological Diversity of Royal Belum" 2-4 November 2008 Hotel Syuen, Ipoh Published by Dept of Wildlife and National Parks Peninsular Malaysia. pp 30

Forsythe T. G. (1987). The relationship between body form and habit in some Carabidae (Coleoptera). J. Zool. Soc. London. 211: 643-666

Grove S.J. (2001). The influence of forest management history on the integrity of the saproxylic beetle fauna in Australian lowland tropical rainforest. Biol. Conservation. Vol. 104 (2): 146-171.

Hammond, P. M. (1995). Described and estimated species numbers: an objective assessment of current knowledge. In Microbial diversity and ecosystem function (ed. D. Allsopp, R. R. Colwell and D. L. hawksworth). 29-71 pp. Wallingford, UK: CAB International.

Hunter M. L. (1999). Maintaining biodiversity in forest ecosystems. Cambridge University Press.

Idris A. B., Ismail S., Haron Y. and Suhana Y. (2009). Insects of tasik Chini with Special Emphasis on Ichneumonid Wasps. Sains Malaysiana. Vol. 38 (6): 813-816.

Lewis O. T. (2002). Effect of experimental selective logging on tropical butterflies. Conservation Biology. Vol. 15: 389-400. 
Lovei G. L. and Sunderland K. D. (1996). Ecology and behavior of ground beetles (Coleoptera: Carabidae). Annu. Rev. Entomol. 41:231-256.

Melbourne B. A. (1999). Bias in the effect of habitat structure on pitfall traps: An experimental evaluation. Australian Journal of Ecology. Vol. 24: 228-239.

Novotny V., Basset, Y., Miller, S. E., Weiblen, G. D., Bremer, B., Cizek, L. And Drozd, P. (2002). Low host specificity of herbivorous insects in a tropical forest. Nature. 416: 841-844.

Odegaard, F. (2000). Haw many species of anthropods? Erwin's estimate revisited. Boil. J. Linn. Soc. Vol. 71: 583-597.

Prance G. T. (1982). Biological Diversification in the Tropics. New York. Columbia University Press.

Stork, N. E. (1988). Insect diversity: facts, fiction and speculation. Biol. J. Linn. Soc. Vol. 35: 321-337.

Sundufu A. J. and Rashida D. (2008). Habitat preferences of butterflies in the Bumbuna forest, Northern Sierra Leone. Journal of Insect Science. Vol. 8: 64.

Terborgh J. (1999). Requiem for nature. Island Press.

Triplehorn, C.AS. and N.F. Johnson. 2004. Borror and DeLong's Introduction to the Study of Insects. Brooks Cole 